\title{
THE CRITERIA OF SITE SELECTION FOR FARMERS’ MARKETS
}

\author{
Dorottya SZABÓ ${ }^{\mathrm{a}}$ \\ a Institution: Research Institute of Agricultural Economics, Address: 1093 Budapest, Zsil utca 3-5., e- \\ mail: szabo.dorottya@aki.gov.hu
}

Cite this article: Szabó, D. (2016). The Criteria of Site Selection for Farmers' Markets. Deturope, 8, 3: $185-201$

\begin{abstract}
Over the past few years the number of farmers' markets in Hungary has considerably grown what was induced both by the growing demand and the occurrence of facilitated authorization requirements. At the same time according both to international and Hungarian experience the dynamic increase in the number of farmers' markets has occurred together with a notably high closure rate.

Markets having characteristically small number of vendors, narrow variety of products, unsatisfactory organizing capacity and experience, as well as markets operating at an inadequate site were generally closed during the first four years.

The present study aims to describe a factor system relevant for the site selection of markets that was made measurable by the adaption of a multi dimension criteria system developed in the United States of America for domestic circumstances. The final aim is the development of a toolkit that can help in the evaluation by this in the comparison of the existing and potential markets sites in Hungary.
\end{abstract}

Keywords: short supply chain, farmers' market, site selection, multi-dimension method

\section{INTRODUCTION}

In Hungary, types of short supply chains (SSC) that are modern, innovative or bearing moral values (e.g. novel farmers' markets, community supported agriculture, box scheme, consumer communities) have occurred recently. At the moment purchasing at a market is the most favoured type of short supply chains that is proved by considerably increasing number of farmers' markets in the past few years in Hungary. Defining the boundaries of markets by their characteristics/nature encounters difficulties as since the Ministry for Agriculture (MA) Decree 51/2012. (VI. 8.) entered into force in June 2012, the National Food Chain Safety Office (NÉBIH) has been counting exclusively markets registered according to the Decree ${ }^{14}$. Although among sites approved as 'conventional' markets there are markets where only selling by farmers is approved by the organizers, commercial selling is not allowed. Despite, the dynamic increase in the number of farmers' markets is indisputable, mainly since the introduction of facilitated approval.

\footnotetext{
${ }^{14}$ Ministry for Agriculture Decree 51/2012. (VI. 8.) MA Decree on the food safety criteria of trading at local farmers markets
} 
At the same time a study by Stephenson, Lev and Brewer (2008) shows that a dynamic increase in the number of farmers' markets occurred together with a rather high closure rate nearly $30 \%$ - in the United States. Markets, having characteristically small number of vendors, narrow variety of products, unsatisfactory organizing capacity and experience, as well as markets operating at an inadequate site, were generally closed during the first four years.

It was also emphasized by Lohr et al. (2011) that along with the increase in the number of farmers' markets, many of them close as well. For example, in Oregon 62 farmers' markets opened between 1998 and 2005 and 32 closed, with similar annual rates. In this case the site selection was highlighted by the authors as a factor of competition for farmers and customers. The high number of closing markets indicates that opening a market could be accompanied by high-level risk, and the probability of failure probability of failure by the increment of competition for farmers and customers.

Although the majority of Hungarian farmers' markets are still in the critical four years since the initiation of their operation, and numerical data have not been published on this topic yet, closing of markets functioning unsustainably can be observed already in Hungary too.

Main aspects of the sustainable functioning of farmers' markets are appropriate planning, proper product composition that is in accordance with the demand, finding farmers for this reason, estimation of the available supply, besides the optimal site selection, what is regardless of whether temporary or permanently functioning markets are considered.

The present study is focused on the latter one as there has not been published any methodology on the site selection of farmers' markets in Hungary yet. The aim of the study is the adaption of a multi dimension criteria system applied in practice in the United States of America for domestic circumstances. I have not found yet in Europe similar site selection system.

\section{MATERIALS AND METHODS}

First of all, changes in the number of farmers' markets between 2012 and 2014 are shown in the study. Data were collected by the National Food Chain Safety Office (NÉBIH).

The system was built up by Matthew Peters (2008) based on his research, that focuses particularly on the measurability of markets site selection.

As a first step for adaption, competent Hungarian experts were assembled, in the frame of the event Terra Madre that was organized by the Ministry for Agriculture in December 2014.

The primary aim of the workshop besides the re-evaluation of Peters's criteria was the revision of the aspects for elimination of questions irrelevant for Hungarian circumstances 
and for integration of criteria that are not analysed by the original study however they have notable effect in Hungary regarding the contributing experts' opinions.

Prior to the workshop all participants were asked to fill in an online questionnaire to evaluate and if necessary supplement the given criteria. Different to the North American practice, experts were not asked to distribute 100 points between 26 criteria, but to score the site selection criteria by the use of a scale from 0 to 10 , where 0 meant that the given factor has no significance regarding the site selection of a farmers' market, and 10 meant that the given criterion is essential for the sustainable functioning of a market. All of these aspects were analysed from the point of view of three stakeholders, as the producers selling at the market, the market organizers and the potential customers. Experts were asked to evaluate separately these often diverse expectations of actors. During the workshop 20 participants worked, in 4 small working groups. Preferably a scientific expert, a producer, a market organizer, occasionally an official veterinarian and another expert who was able to evaluate the criteria from a consumers' point of view, was represented in each group. Although the applied methodology is under development, firstly the determined scores were totalized and the results were expressed in terms of percentage compared to the total score, so weights applied by Peters were gained in this way.

\section{CHARACTERISTICS OF FARMERS' MARKETS}

\section{Definition and types of short supply chain}

According to Article 2 (m) of Regulation 1305/2013/EU of the European Parliament and of the Council the definition of the 'short supply chain': definition is a supply chain involving a limited number of economic operators, committed to co-operation, local economic development, and close geographical and social relations between producers, processors and consumers. That is producers or a group of producers are selling their food products directly to consumers or a group of consumers, or through one intermediate actor.

Short supply chains that are selling directly or through one intermediary can be classified into four main types and two subtypes (Tab. 1).

Table 1 Marketing types of SSC

SSC type: For intermediaries

Traditional: Directly marketed processor

Modern: Catering, canteen meals, retail trade

\section{SSC type: Open farm}

Traditional: Store at the farmyard, "pick-your-own", rural catering

Modern: Community Supported Agriculture

\section{SSC type: Delivery}

Traditional: Door-to-door sale, Moving sale (mobile shop)

Modern: Box system, Online delivery

\section{SSC type: Points of sale (POS)}

Traditional: Marketplace, fair, temporary relocation

Modern: Farmers market, feast, farm shop in settlement, vending machine

Source: SFC2014 Short supply chain thematic sub-programme, DRAFT, 2014 


\section{Farmers' markets in Hungary}

Classification of markets should be based on SSC sales types taking into consideration recent types of food retail and the characteristics of supply chains as well:

- Traditional (permanent) markets: are usually bigger in size, roofed, hall-like markets, that can be open-air or half roofed or a combination of these. Vendors and producers are organized miscellaneously, more or less separated or in a well separated manner.

- Modern farmers' markets: are generally temporary or permanent markets, where solely producers are selling their own produces. These markets are mainly but not necessarily operating according to the legislation entered into force in 2012 regarding farmers' markets. ${ }^{15}$

Data regarding famers market per each county is being collected by the NÉBIH since 2012. Changes in the number of markets between 2012 and 2015 are demonstrated on Figure 1 and the dynamic increasing of this market types can be clearly observed. While 118 farmers' markets were registered by the Office in 2012, in January 2015 the number of farmers' markets reached the total of 214 that means an increase by $81 \%$, and possibly further growth can be expected in the future.

Figure 1 Number of markets and distribution by type (2012-2015)

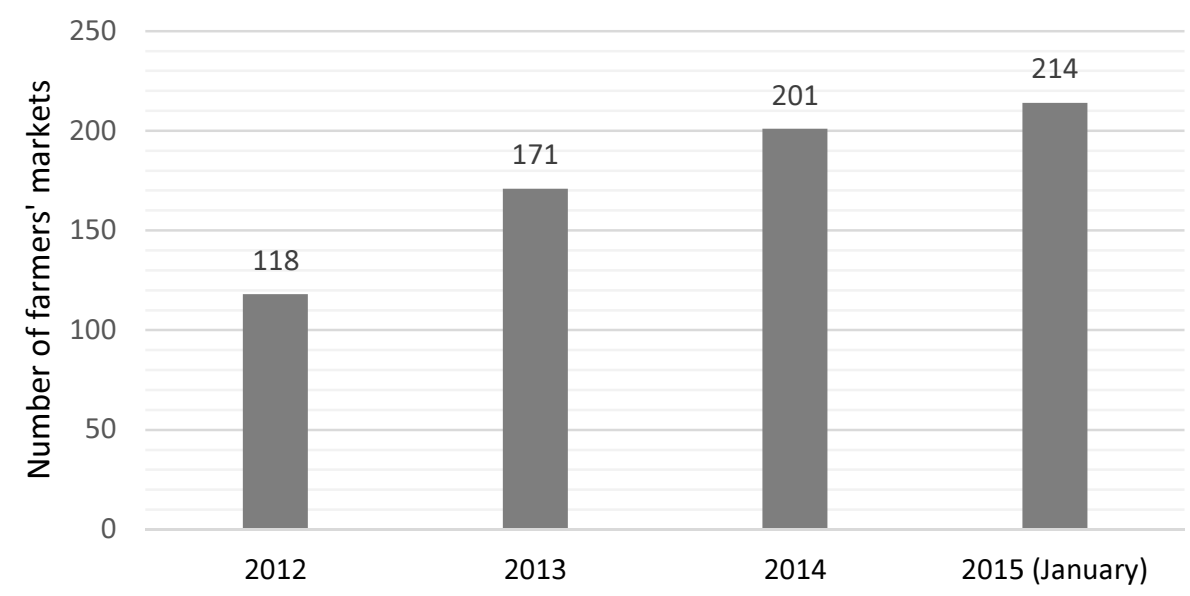

Source: own construction based on the compilation made by NÉBIH (2012-2015)

Information on the location and the distribution of farmers' markets provided by NÉBIH as well. According to the data registered most of the farmers' markets operated in Pest County

\footnotetext{
${ }^{15}$ This category is defined by the Act CLXIV. of 2005 on trade, what is a legislative category and sales type specifically established for small producers that has not existed before (MA Decree 51/2012. (VI. 8.) on the food safety criteria of trading at local farmers' markets). On local farmers markets exclusively those small producers who are registered and fulfil the requirements of the Decree 52/2010, besides saling has to be located in the county of the farm or within a $40 \mathrm{~km}$ range, or in Budapest.
} 
and in Budapest at the time of analysis. $25 \%$ of all local markets were found in the region of Central Hungary, what was followed by Csongrád County with the number of 22 markets. In Komárom-Esztergom County 15, in Borsod and Békés Counties 14-14 farmers' markets were operating in the examined period. At the beginning of 2015 there was only one market of this kind in the area of Hajdú-Bihar County. Nógrád, Jász-Nagykun-Szolnok, Bács-Kiskun and Győr-Moson-Sopron Counties did not abound in farmers' markets either with the number of two, three and five markets. Remaining Counties are ranked in the middle with a market number between six and twelve. The location of farmers' markets in Hungary are illustrated in Figure 2.

Figure 2 The location of farmers' markets in Hungary (2015)

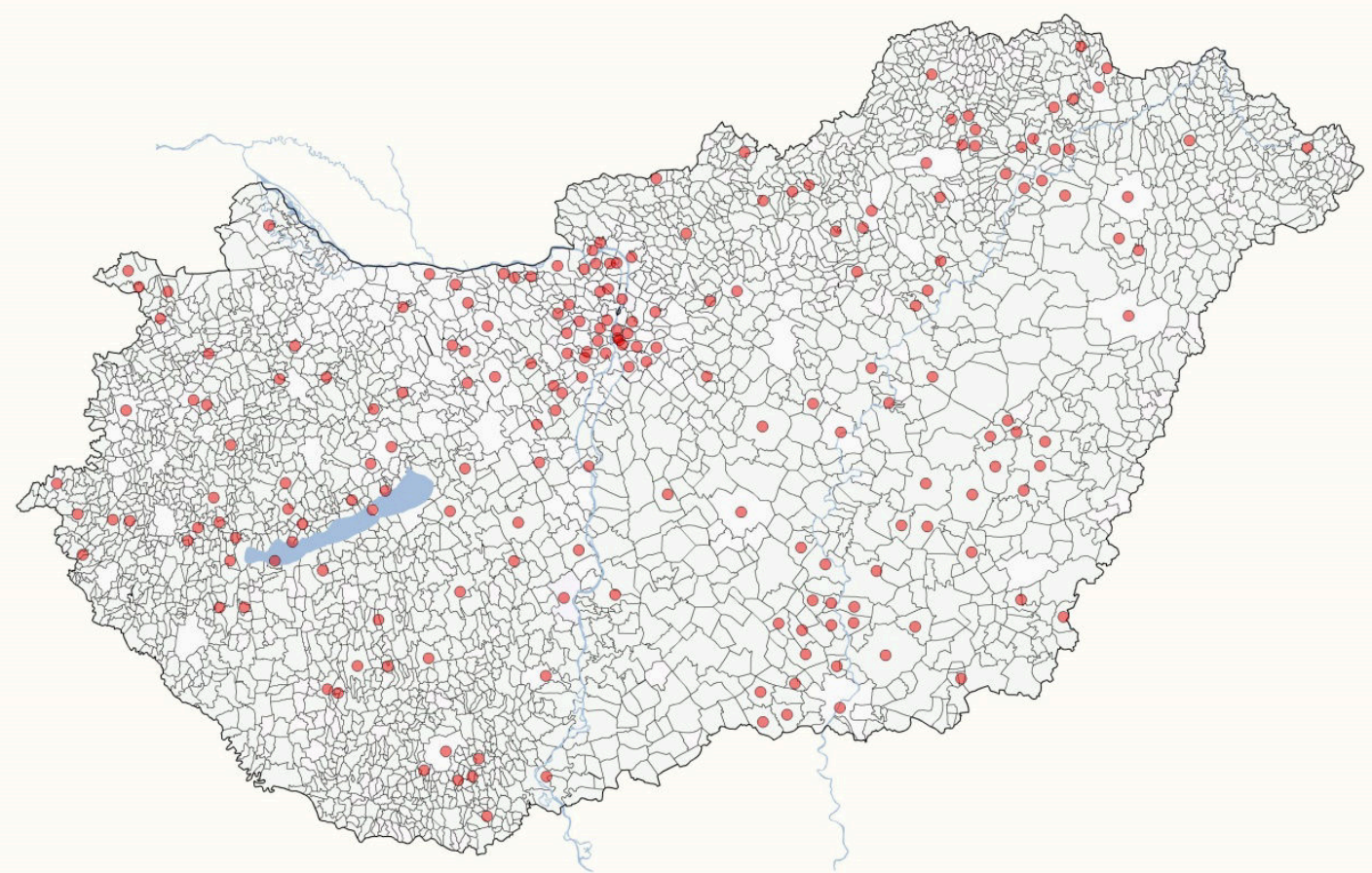

Source: own construction based on the compilation made by NÉBIH (2015).

Created with GEO Market

Information on closed farmers' markets is not available at the moment. Thus further research is needed for the determination of the actual number of functioning farmers' markets.

\section{THE CRITERIA OF SITE SELECTION FOR FARMERS' MARKETS: EXPERIENCES IN THE UNITED STATES}

The available scientific literature regarding farmers' markets is concentrated in the United States as well as it means an enormous amount of publications including research studies, surveys, and also manuals for market organizers and producers. At the same time, only a few 
of these publications deal exclusively with market site selection as well as its measurability, however its importance is emphasized by almost all studies. Unfortunately, relevant scientific literature in Europe (written in English) is lacking, therefore appropriate comparison of Hungarian and European circumstances is not achievable.

According to Lohr et al. (2011) the most competitive zones are in the urban areas. The competition for producers in urban areas is greater than the competition for consumers, as vendors have to travel more to reach farmers' markets than consumers.

Although producers cannot definitely reach higher sale prices in urban areas, the number of customers circulating is higher than in rural areas that means a strong motivation for vendors to expend time on selling at a market.

During site selection and planning of actuation, opening hours that differ from opening hours of nearby markets, establishment of unique marketing aspects, focusing on the characteristics of the site such as parks, environment, nearby retailers offering goods that can supplement the supply of the market, are all remarkable factors that can help to make the market more appealing for consumers.

According to the opinion of the Northeast Organic Farming Association (2009) it is of key importance to find the best place for a farmers' market regarding the success of the market. The Association recommended fifteen different aspects to think about, and supporting questions were provided for the organizers as well.

A handbook was prepared by Jolly in 2005 for launching new farmers' markets, wherein site selection was highlighted also. Criteria that were considered to be significant regarding site selection of markets were described similarly to the previously mentioned studies. Factors that were listed by Jolly were all explained based on the author's experiences.

Vance Corum (2009), as an experienced market organizer, in respect of site selection of famers' markets concluded that a good farmers' market creates a sense of place. Corum created a toolkit for the evaluation of the site selection (Site Evaluation Tool $=$ SET). SET offers an analysis with 16 factors that helps to focus on the relative strengths and weaknesses of all sites. Thus it hopefully leads to a consultation between stakeholders involved in the establishment of the market that results in a successful site selection. It is important to mention that the tool was applied as an incentive, supporting decision making, rather than a perfect analysing tool. Factors displayed in Table 2 were taken into consideration and were ranked by the assigned values; they also made the comparison of potential sites possible. According to Corum, the extent of the scores is debatable since only one expert is not enough to evaluate objectively the criteria influencing markets' site selection. The aim is to achieve 
community decision making that is supported by the set of criteria decision and the weights applied.

Table 2 Factors influencing the site selection of farmers' markets according to Corum (2008)

\begin{tabular}{cc}
\hline Criteria & Maximum points \\
\hline Visibility (Traffic) & 18 \\
Parking & 12 \\
Signage Potential & 10 \\
Permanence & 10 \\
Size (Expansion Potential) & 8 \\
Business Proximity & 7 \\
Cost (Site/Security/Insurance) & 7 \\
Weather Protection & 6 \\
Vehicle Access & 4 \\
Slope \& Surface & 4 \\
Aesthetics/Atmosphere & 3 \\
Public Transport & 3 \\
Restrooms & 2 \\
Facilities (Water/Elec/Recy) & 2 \\
Storage & 2 \\
Landmark & 2 \\
\hline TOTAL & $\mathbf{1 0 0}$ \\
\hline Source: 0 (awn & \\
\hline construction based on Corum (2008) & \\
\hline
\end{tabular}

Source: own construction based on Corum (2008)

On the whole, it can be concluded that the elaborated criteria system, that was based on the set of criteria established in the United States, considered mainly similar aspects regarding site selection of farmers' markets. Factors considered are as follows: accessibility, public transport, parking, permanence, distance from the closest retail zone, restrooms, facilities, community places, atmosphere, environment, weather protection, visibility.

\section{Description of the adapted study}

The system was built up by Matthew Peters (2008) based on his own research, that focuses particularly on the measurability of markets' site selection. Peters took the results of Vance Corum as a basis and created a multidimensional criteria system similar to the one set up by Corum. Instead of a scoring system, Peters applied a method that included, in case of each criterion, the comparison of relative high and low values and the appropriate answers were standardised in all fields. Then criteria were weighted based on the ranking of experts of farmers' market involved in the work. All participants had to share 100 scores among the criteria regarding their importance. Thus the criterion that was proven to be the most important got the highest score. Answers were averaged and each factor was weighted with those values. Three different weight systems were designed and those were representing the 
interest of different actors (organizers, vendors, customers). Besides, a standardised weight system was applied, where each group was represented equally.

Based on Peters' research results, concerning the opinion of market organizers the most important criteria of farmers' market site selection were ability to stay at site in the future and rent for the site. Farmers put in the first place the long term ability of markets and the second most important condition was the level of residential density. The highest scores were given to the parking with a 2-hour limit and the size of farmers' market by customers (Tab. 3).

Table 3 Averaged Criteria Weights by Peters (2008)

\begin{tabular}{|c|c|c|c|c|c|}
\hline & & $\begin{array}{c}\text { Market } \\
\text { Organizer }\end{array}$ & Farmer & Customer & Together \\
\hline \multirow{12}{*}{ Locational } & Distance from Formers Farmers Market Site & 5,2 & 3,8 & 5,0 & 4,6 \\
\hline & Distance to Neighbourhood Retail Core & 3,6 & 3,3 & 6,8 & 4,6 \\
\hline & Distance to Community Landmark & 2,3 & 1,5 & 3,5 & 2,4 \\
\hline & Residential Density & 5,2 & 7,9 & 4,4 & 5,8 \\
\hline & Traffic Intensity & 3,6 & 3,3 & 2,3 & 3,1 \\
\hline & Transit Accessibility & 3,6 & 0,9 & 4,1 & 2,9 \\
\hline & Bike Parking & 1,1 & 0,4 & 3,0 & 1,5 \\
\hline & Parking with 2 hr limit & 4,5 & 6,0 & 10,4 & 7,0 \\
\hline & Pay for Parking & 2,9 & 2,0 & 4,6 & 3,2 \\
\hline & Nearby Sidewalks & 2,9 & 1,3 & 5,3 & 3,1 \\
\hline & Availability of off-site parking for farmers & 3,9 & 6,1 & 0,4 & 3,4 \\
\hline & Visibility & 5,0 & 7,1 & 4,2 & 5,5 \\
\hline \multirow{11}{*}{ Physical } & Size & 6,6 & 5,9 & 8,3 & 6,9 \\
\hline & Layout of Market & 0,0 & 0,0 & 0,0 & 0,0 \\
\hline & Surface Condition & 5,5 & 4,9 & 3,6 & 4,7 \\
\hline & Grade & 4,1 & 4,6 & 3,3 & 4,0 \\
\hline & Number of possible entrances & 1,4 & 2,0 & 3,9 & 2,4 \\
\hline & Public Restrooms & 3,0 & 2,9 & 4,4 & 3,5 \\
\hline & Covered Area & 2,7 & 5,1 & 3,7 & 3,8 \\
\hline & Shaded Area & 2,9 & 4,2 & 4,2 & 3,8 \\
\hline & Electricity & 3,8 & 4,8 & 1,5 & 3,3 \\
\hline & Lights for night & 2,2 & 2,7 & 2,1 & 2,3 \\
\hline & Storage & 5,4 & 0,6 & 0,0 & 2,0 \\
\hline \multirow{4}{*}{$\begin{array}{l}\text { Use } \\
\text { Agreement }\end{array}$} & Cost to use site & 6,8 & 5,3 & 0,5 & 4,2 \\
\hline & Ability to stay at site into the future & 8,0 & 9,2 & 4,2 & 7,1 \\
\hline & Days/Time available for use & 4,0 & 4,2 & 6,3 & 4,8 \\
\hline & Total & 100 & 100 & 100 & 100 \\
\hline
\end{tabular}

Source: own construction based on Peters (2008)

\section{ELABORATION OF SITE SELECTION CRITERIA FOR HUNGARY}

Site selection criteria of farmers' markets were divided into six categories. The determined six categories are as follows: location, accessibility, parking, arrangement, infrastructure, land- 
use. For the determination of factors, Peters' definitions were used as starting points that were provided to the participants during the preliminary online evaluation (Tab. 4).

Table 4 Description of the criteria analysed by experts

\begin{tabular}{|c|c|c|}
\hline Dimensions & Criteria & Description \\
\hline \multirow{5}{*}{ 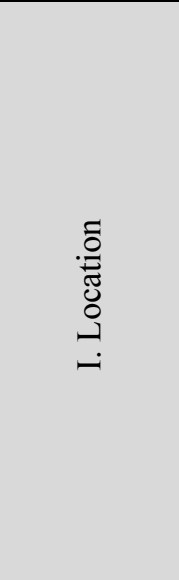 } & $\begin{array}{l}\text { 1. Distance from the } \\
\text { Closest } \\
\text { Market Site }\end{array}$ & $\begin{array}{l}\text { The measurement of the distance of current farmers' market site from } \\
\text { the closest (farmers') market, expressed in mile. }\end{array}$ \\
\hline & $\begin{array}{l}\text { 2. Distance from the } \\
\text { Closest Retail Centre }\end{array}$ & $\begin{array}{l}\text { The measurement of the distance of current farmers' market site from } \\
\text { the closest community business district, expressed in mile. }\end{array}$ \\
\hline & $\begin{array}{l}\text { 3. Distance from } \\
\text { Community } \\
\text { Places/Public Spaces }\end{array}$ & $\begin{array}{l}\text { The measurement of the distance of site from well known community } \\
\text { places, expressed in mile }\end{array}$ \\
\hline & 4. Visibility & $\begin{array}{l}\text { Total number of streets that lead directly to the market (or where } \\
\text { there is open space or a parking lot between the street and the } \\
\text { market). }\end{array}$ \\
\hline & 5. Population Density & $\begin{array}{l}\text { This criterion is the measurement of the number of people living } \\
\text { within } 500 \text { meters of the farmers' market site. }\end{array}$ \\
\hline \multirow{4}{*}{ 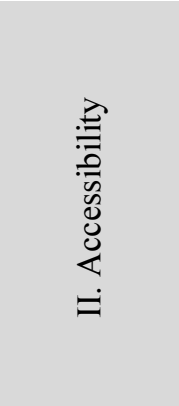 } & 1. Traffic Intensity & $\begin{array}{l}\text { This criterion is measured by counting the number of daily trips } \\
\text { travelled on arterials within a quarter-mile of the site. }\end{array}$ \\
\hline & $\begin{array}{l}\text { 2. Accessibility by } \\
\text { Public Transport }\end{array}$ & $\begin{array}{l}\text { The number of public transport routs (tram, bus, metro, train, etc.) } \\
\text { stopping in a one-hour course within a radius of } 200 \text { meters during } \\
\text { the opening hours of the market. }\end{array}$ \\
\hline & 3. Bike Parking & The number of spaces in bike racks adjacent or onsite. \\
\hline & 4. Nearby Sidewalks & $\begin{array}{l}\text { The measurement of the percentage of the blocks within a radius of } \\
\text { an eighth of a mile that have sidewalks. }\end{array}$ \\
\hline \multirow{3}{*}{ 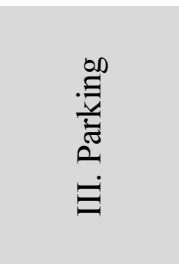 } & $\begin{array}{l}\text { 1. Free parking with a } 2 \\
\text { hr limit }\end{array}$ & $\begin{array}{l}\text { The number of street parking spots within a radius of an eighth of a } \\
\text { mile with a time limit of two hours or shorter that is free to use. }\end{array}$ \\
\hline & $\begin{array}{l}\text { 2. The extent of nearby } \\
\text { parking fees }\end{array}$ & $\begin{array}{l}\text { The number of parking spots within a radius of an eighth of a mile } \\
\text { where the user must pay for parking. }\end{array}$ \\
\hline & $\begin{array}{l}\text { 3. Available off-site } \\
\text { parking for farmers }\end{array}$ & $\begin{array}{l}\text { This criterion is a measurement of the area available for farmers to } \\
\text { park vehicles off-site. }\end{array}$ \\
\hline \multirow{6}{*}{ 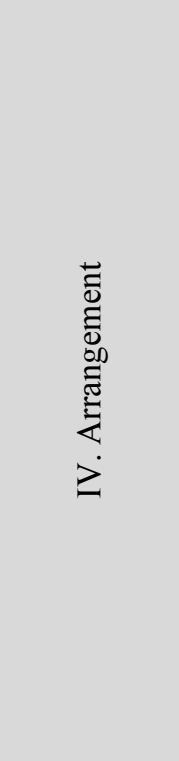 } & 1. Size & The size of the market place, expressed in square meters. \\
\hline & 2. Layout of Market & $\begin{array}{l}\text { No adequate measurement has been established for this criterion. } \\
\text { While it was deemed to be an important factor in evaluating the site } \\
\text { through the result of the weighting exercise, this criterion has been } \\
\text { omitted from the site selection calculations. }\end{array}$ \\
\hline & 3. Slope & $\begin{array}{l}\text { This criterion is the degree of the gradient of the site. The } \\
\text { classification is as follows: class } 0 \text { is for a steep slope. Class } 1 \text { is for a } \\
\text { moderate incline. Class } 2 \text { is for a slight slope. Class } 3 \text { is for a flat or } \\
\text { fairly flat site. }\end{array}$ \\
\hline & 4. Possible Entrances & $\begin{array}{l}\text { This criterion measures the flexibility of the site to accommodate } \\
\text { different entrance options. This criterion is used to measure the } \\
\text { flexibility experienced by customers regarding entering and exiting } \\
\text { the market. }\end{array}$ \\
\hline & 5. Covered Area & The size of the permanently covered area, expressed in square meters \\
\hline & 6. Shaded Area & $\begin{array}{l}\text { The size of the shaded area, expressed in square meters, on the days } \\
\text { when the sun is the highest. }\end{array}$ \\
\hline
\end{tabular}


Table 4 (continued)

\begin{tabular}{|c|c|c|}
\hline Dimensions & Criteria & Description \\
\hline \multirow{5}{*}{ 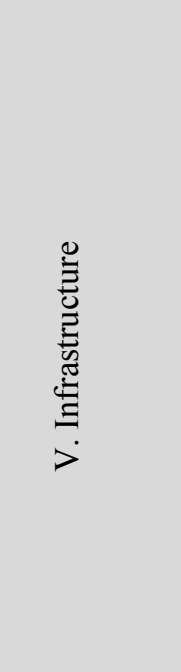 } & 1. Public Restrooms & $\begin{array}{l}\text { This criterion accounts for restrooms are available for vendors and } \\
\text { for the general public within } 30 \mathrm{~m} \text { of the site. }\end{array}$ \\
\hline & 2. Electricity & The number of plugs available for vendors. \\
\hline & 3. Lights for night & $\begin{array}{l}\text { This criterion tracks the range of lighting present on the site for night } \\
\text { use. }\end{array}$ \\
\hline & 4. Surface Condition & $\begin{array}{l}\text { This criterion is the rating of the type of surface of the site where the } \\
\text { market will be located. The quality of the surface must be placed on } \\
\text { the following scale: } 0 \text { - Soil, } 3 \text { - Gravel with an uneven surface, } 4- \\
\text { Grass, } 6 \text { - Asphalt with an uneven surface, } 8 \text { - Gravel with an even } \\
\text { surface, } 10 \text { - Asphalt with an even surface. }\end{array}$ \\
\hline & 5. Storage & The size of the area of available storage on the site. \\
\hline \multirow{3}{*}{ 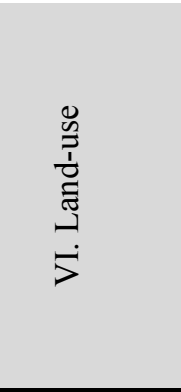 } & 1. Costs of rental & $\begin{array}{l}\text { This criterion is the measurement of daily rental costs, expressed in } \\
\text { HUF. }\end{array}$ \\
\hline & $\begin{array}{l}\text { 2. Ability to stay at site } \\
\text { into the future }\end{array}$ & $\begin{array}{l}\text { The number of years of operation at a given place (the measurement } \\
\text { of the length of the initial lease, plus the length of the first renewal } \\
\text { option). }\end{array}$ \\
\hline & $\begin{array}{l}\text { 3. Opening Hours } \\
\text { (Availability for Use) }\end{array}$ & $\begin{array}{l}\text { This criterion is the number of days during which the site is available } \\
\text { for use during desired market times, which includes preparation and } \\
\text { take down requirements. }\end{array}$ \\
\hline
\end{tabular}

Source: own construction based on Peters (2008)

\section{RESULTS}

Regarding the evaluation of each criterion there was consensus among participants in all groups. Scores given by the four working group and scores from the preliminary individual evaluation were averaged and the results are detailed in Table 5. Since it became clear that multiple averaging is not a suitable method for obtaining the definite weights, results represented in this paper are not considered to be ultimate, but can be interpreted as partial results of the workshop.

Criteria related to parking were adjudicated to be the most remarkable expectation, with an average value of 8.7 , by experts. It was followed by the dimension of land-use (average: 7.7), then requirements related to location (average: 7.4). Factors related to arrangement of the market were fourth in the row (average: 7.0), aspects of infrastructure and accessibility with the average of 6.9 and 6.6, respectively, came last. If aspects of actors are examined separately results slightly differing from average values are obtained. Regarding the viewpoint of market organizers, dimension of land-use was determined to be the most 
important with an average value of 8.9. It was followed by factors of parking and location. In this case the most irrelevant criterion was the accessibility, with an average score of 6.5. With respect to the viewpoint of producers, the most substantial factor was parking (average: 8.7), however land-use - that involves opening hours and ability to stay at site in the future as well - gained similarly high ratings from experts (average: 8.4). Accessibility seemed to be the most negligible set of criteria, like in the case of market organizers. It received not more than 5.8 scores. At the same time, regarding aspects of customers, this dimension was evaluated to be the most important together with factors of parking. The lowest score was given to infrastructure, in average (Tab. 5).

Table 5 Average scores given by workgroup

\begin{tabular}{|c|c|c|c|c|c|c|c|c|}
\hline \multirow[b]{2}{*}{ Criteria } & & \multicolumn{3}{|c|}{ Actors } & \multicolumn{4}{|c|}{ Altogether } \\
\hline & & $\begin{array}{c}\text { Market } \\
\text { Organizer }\end{array}$ & Farmer & Customer & Average & Min & Max & Dev. \\
\hline \multirow{5}{*}{ I. Location } & 1 . & 7,6 & 8,1 & 7,2 & 7,6 & 2,7 & 10,0 & 1,7 \\
\hline & 2. & 6,5 & 6,0 & 7,3 & 6,6 & 0,0 & 10,0 & 2,4 \\
\hline & 3. & 7,6 & 7,5 & 7,8 & 7,6 & 2,7 & 10,0 & 2,2 \\
\hline & 4. & 8,2 & 7,9 & 8,1 & 8,0 & 2,3 & 10,0 & 1,7 \\
\hline & 5. & 7,9 & 7,5 & 5,6 & 7,0 & 3,0 & 9,0 & 1,4 \\
\hline \multicolumn{2}{|c|}{ Location - average } & 7,54 & 7,5 & 7,4 & 7,2 & 7,4 & 2,5 & 2,5 \\
\hline \multirow{4}{*}{ II. Vehicle access } & 1. & 6,6 & 7,1 & 7,0 & 6,9 & 2,7 & 9,3 & 1,7 \\
\hline & 2. & 7,6 & 6,0 & 8,5 & 7,4 & 2,0 & 10,0 & 1,9 \\
\hline & 3. & 5,5 & 4,4 & 6,9 & 5,6 & 1,7 & 10,0 & 2,1 \\
\hline & 4. & 6,3 & 5,8 & 7,7 & 6,6 & 2,3 & 10,0 & 1,9 \\
\hline \multicolumn{2}{|c|}{ Vehicle access - average } & 6,51 & 6,5 & 5,8 & 7,5 & 6,6 & 2,2 & 2,2 \\
\hline \multirow{3}{*}{ III. Parking } & 1. & 8,5 & 8,9 & 9,0 & 8,8 & 3,0 & 10,0 & 1,6 \\
\hline & 2. & 7,7 & 8,4 & 8,3 & 8,1 & 2,7 & 10,0 & 1,7 \\
\hline & 3. & 8,3 & 9,0 & 4,7 & 7,3 & 0,0 & 10,0 & 2,2 \\
\hline \multicolumn{2}{|c|}{ Parking - average } & 8,14 & 8,1 & 8,7 & 7,4 & 8,1 & 2,7 & 2,7 \\
\hline \multirow{6}{*}{ IV. Arrangement } & 1. & 8,0 & 7,5 & 8,0 & 7,8 & 2,7 & 10,0 & 1,8 \\
\hline & 2. & 6,5 & 7,1 & 6,4 & 6,7 & 1,7 & 10,0 & 2,3 \\
\hline & 3. & 7,1 & 7,1 & 6,8 & 7,0 & 1,0 & 10,0 & 2,2 \\
\hline & 4. & 6,1 & 6,1 & 6,4 & 6,2 & 1,0 & 10,0 & 2,6 \\
\hline & 5. & 6,8 & 7,5 & 7,1 & 7,1 & 0,0 & 10,0 & 2,8 \\
\hline & 6. & 6,7 & 8,3 & 7,4 & 7,5 & 3,0 & 10,0 & 1,8 \\
\hline \multicolumn{2}{|c|}{ Arrangement - average } & 6,86 & 6,9 & 7,3 & 7,0 & 7,0 & 2,8 & 2,8 \\
\hline \multirow{5}{*}{ V. Infrastructure } & 1. & 8,6 & 9,1 & 7,7 & 8,4 & 3,0 & 10,0 & 1,8 \\
\hline & 2. & 8,6 & 8,6 & 5,0 & 7,4 & 3,0 & 10,0 & 1,7 \\
\hline & 3. & 6,8 & 6,9 & 6,8 & 6,8 & 0,0 & 10,0 & 3,0 \\
\hline & 4. & 6,8 & 6,3 & 7,0 & 6,7 & 1,3 & 10,0 & 2,2 \\
\hline & 5. & 5,9 & 6,0 & 3,0 & 5,0 & 0,0 & 8,7 & 2,8 \\
\hline \multicolumn{2}{|c|}{ Infrastructure - average } & 7,34 & 7,3 & 7,4 & 5,8 & 6,9 & 2,7 & 2,7 \\
\hline \multirow{3}{*}{ VI. Land-use } & 1. & 8,6 & 8,4 & 3,9 & 6,9 & 0,0 & 9,0 & 2,1 \\
\hline & 2. & 9,1 & 8,9 & 8,0 & 8,7 & 3,0 & 10,0 & 1,6 \\
\hline & 3. & 7,4 & 7,9 & 7,6 & 7,6 & 1,0 & 10,0 & 2,2 \\
\hline \multicolumn{2}{|c|}{ Land-use - average } & 8,36 & 8,4 & 8,4 & 6,5 & 7,8 & 2,8 & 9,2 \\
\hline
\end{tabular}


Figure 3 Distribution of the evaluated dimensions by the results of scoring (\%)

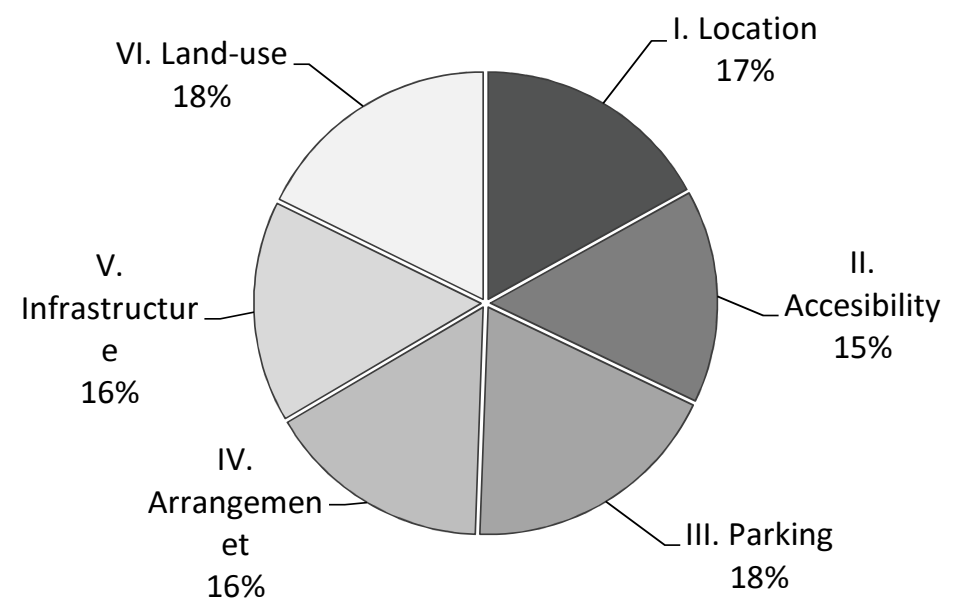

Source: own construction (2015)

In order to obtain (temporarily not final) weights of the analysed criteria, percentage of the average values belonging to criteria was calculated (results of ranking of criteria by the application of the 11-degree scale were not affected).

First of all, the distribution of dimensions was analysed in order to decide which criterion determining the site selection of farmers' market was considered to be the most important by experts, regardless of the number of factors included in each dimension. It can be clearly observed on Figure 3 that the proportion of each dimension was nearly equal. Ranking of dimension did not differ from the results of ranking by scores.

Analysing the criteria one by one, it can be concluded that free parking possibilities were represented with the highest weights that was followed by the ability to stay at site into the future. Remarkable factors were the presence of restrooms and extent of parking fees also. Besides, the visibility and size of the market, the distance from other farmers' market, furthermore opening hours (availability) and the distance from community places participated in the criteria system with a proportion higher than $4 \%$. The lowest scores were given to storage and bike parking (Fig. 4). 
Figure 4 Weight of criteria influencing site selection, in the order of importance

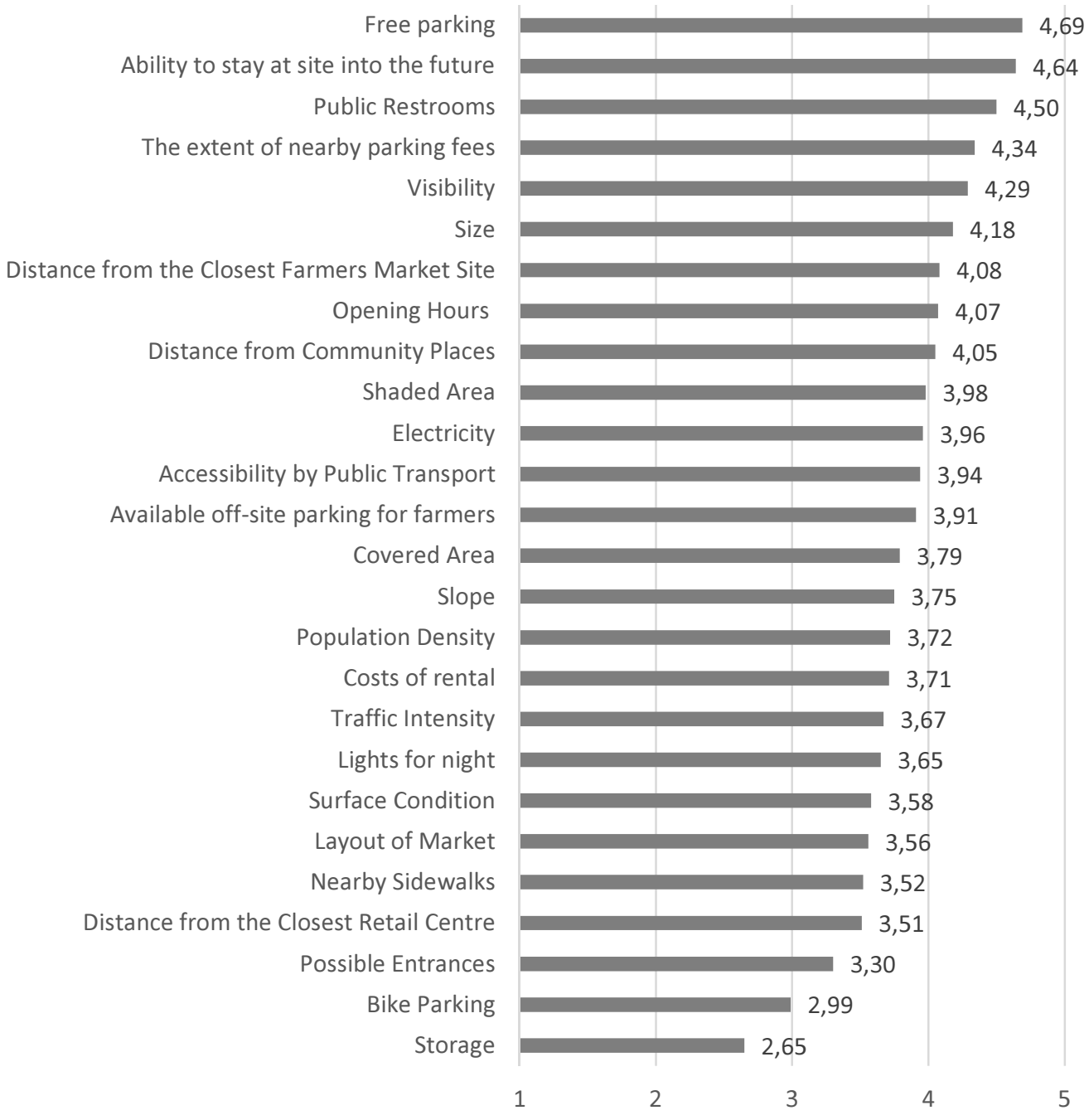

Source: own construction (2015)

Regarding aspects of the three accentuated actor of the farmers' market sales different factors were rated to be relevant by the experts. The most emphasized interest of market organizers was the ability to stay at site into the future. Infrastructure (electricity, restrooms) came after, followed by rental fee and parking possibilities. Weighting of the most valuable criteria by producers showed similarities to the previous ranking. In this case accessibility of restrooms, parking possibilities and the permanence of the market were at the forefront. Evaluating criteria from the viewpoint of customers, parking, public transport, and visibility scored the highest values however the ability to stay at site into the future received higher ratings also (Tab. 6). 
Table 6 Weights related to criteria influencing farmers' market site selection regarding aspects of stakeholders

\begin{tabular}{|c|c|c|c|c|}
\hline \multirow[b]{2}{*}{ Criteria } & & \multicolumn{3}{|c|}{ Actors } \\
\hline & & Market Organizer & Farmer & Customer \\
\hline \multirow{5}{*}{ I. Location } & 1. & 4,0 & 4,2 & 4,0 \\
\hline & 2. & 3,4 & 3,1 & 4,1 \\
\hline & 3. & 4,0 & 3,9 & 4,4 \\
\hline & 4. & 4,3 & 4,1 & 4,5 \\
\hline & 5. & 4,1 & 3,9 & 3,1 \\
\hline \multirow{4}{*}{ II. Accessibility } & 1. & 3,5 & 3,7 & 3,9 \\
\hline & 2. & 4,0 & 3,1 & 4,8 \\
\hline & 3. & 2,9 & 2,3 & 3,9 \\
\hline & 4. & 3,3 & 3,0 & 4,3 \\
\hline \multirow{3}{*}{ III. Parking } & 1. & 4,4 & 4,6 & 5,0 \\
\hline & 2. & 4,0 & 4,4 & 4,7 \\
\hline & 3. & 4,3 & 4,7 & 2,7 \\
\hline \multirow{6}{*}{ IV. Arrangement } & 1. & 4,2 & 3,9 & 4,5 \\
\hline & 2. & 3,4 & 3,7 & 3,6 \\
\hline & 3. & 3,7 & 3,7 & 3,8 \\
\hline & 4. & 3,2 & 3,2 & 3,6 \\
\hline & 5. & 3,5 & 3,9 & 3,9 \\
\hline & 6. & 3,5 & 4,3 & 4,2 \\
\hline \multirow{5}{*}{ V. Infrastructure } & 1. & 4,5 & 4,7 & 4,3 \\
\hline & 2. & 4,5 & 4,5 & 2,8 \\
\hline & 3. & 3,6 & 3,6 & 3,8 \\
\hline & 4. & 3,5 & 3,3 & 3,9 \\
\hline & 5. & 3,1 & 3,1 & 1,7 \\
\hline \multirow{3}{*}{ VI. Land-use } & 1. & 4,5 & 4,4 & 2,2 \\
\hline & 2. & 4,8 & 4,6 & 4,5 \\
\hline & 3. & 3,9 & 4,1 & 4,3 \\
\hline Total & & 100 & 100 & 100 \\
\hline
\end{tabular}

Source: own construction (2015)

\section{Differences between Hungarian and North American weights of the criteria}

Priorities of criteria are different between the two examined countries especially with regard to customers' opinion. Hungarian shoppers emphasize the availability of markets; the North American customers rather vote for the supply. Farmers in Hungary gave more points for convenience aspects than North American farmers who emphasized demand factors. Market organizers have similar views about site selection criteria: the most important circumstance is the sustainability (Tab. 7). 
Table 7 Differences between Hungarian and North American weights of criteria that were selected to be the most important

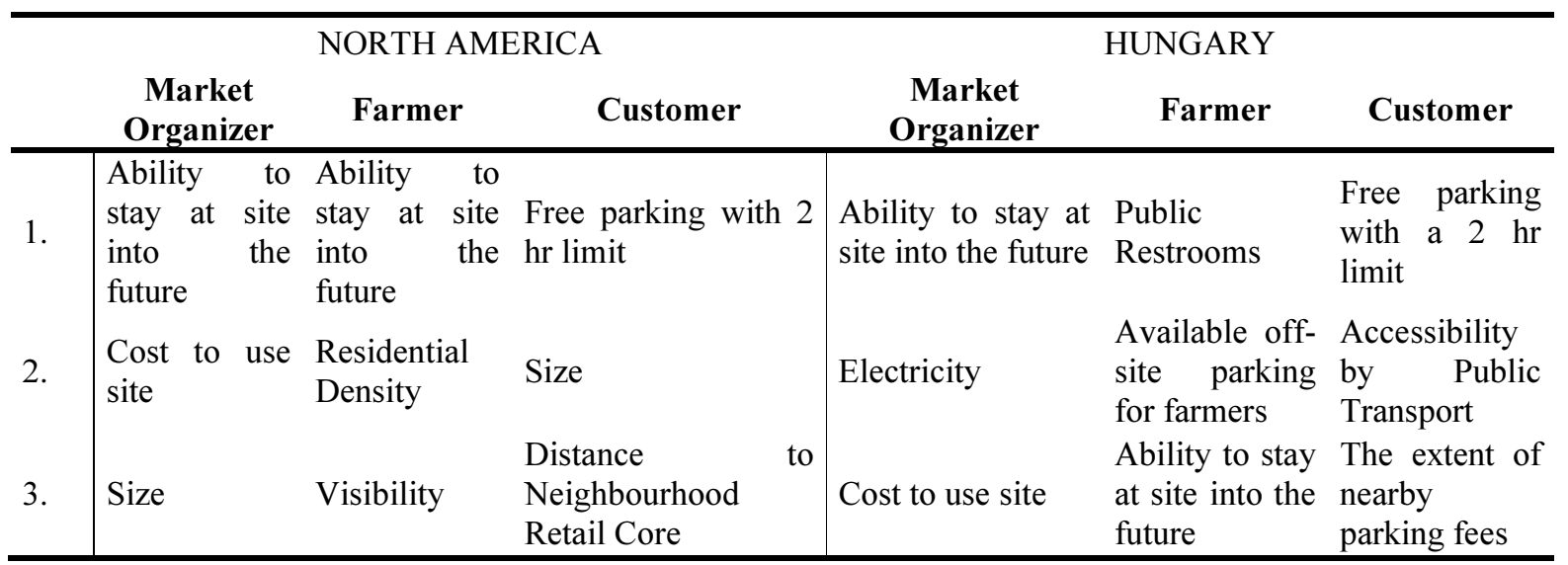

Source: own construction based on Peters (2008) and own survey (2014)

\section{Suggestions regarding the measurability of site selection}

At the end of the workshop, criteria not included in the original study - however they have notable effect in Hungary - were discussed by all four working groups, and further remarks were summarized regarding Peters' methodology.

The ultimate aim is to have farmers' markets that meet the demand of all three actors. According to this, it was considered to be questionable to evaluate the criteria from the three aspects, separately.

It was mentioned as a critique that the analysis of the population density is not adequate enough to map spending power. It is necessary to analyse demographic features, i.e. a more sophisticated survey is needed regarding potential customers than it was elaborated by Peters. In alignment with this the detailed assessment of potential supply of the market is of crucial importance, namely examination of the activity, the product supply and the density of producers is indispensable. Besides, the lack of detailed analysis of solvent demand as a separate dimension was mentioned. It was evaluated as the most important aspect, since it is not independent of the markets' site selection.

In order to achieve that shopping at a farmers' market to be an experience for customers, ensuring public security is required, what was not mentioned in the original study, either. There was no consensus regarding the surface conditions, slope, and lights for night factors. One part of the participants considered these criteria as important factors of a sustainably operating farmers' market; however the other part of the experts rated these factors as irrelevant ones. 
Although differences between criteria of site selection that are important for sustainability of a market in Budapest and/or in the countryside were discussed, the working group was not able to determine a measurable factor as a solution.

According to the success of the Hungarian farmers' markets, tourism is a relevant factor that can be measurable by the number overnight stays, the extent of paid taxes on tourism and/or the distance from highlighted touristic spectacles.

As an important additional factor, distance from municipal markets also (not only the distance from other farmers' markets) were mentioned. Furthermore, frequency of opening hours should be divided into two sections, the seasonality should be taken into consideration as well. There are markets that operate only during a specific period of time, however, it does not mean that those markets are not sustainable.

\section{CONCLUSION}

Present study described the first step of the elaboration of a methodology that aims to make site selection of farmers' market measurable and also aims to provide a method for the comparison of potential sites. During the adaption of a method that was successfully applied in Washington State of United states of America, competent experts analysed and evaluated the criteria of appropriate site selection, in the frame of a workshop. There was consensus among participants regarding evaluation of each criterion, besides, experts agreed on the criteria that were not analysed by the original study however they have notable significance in Hungary. Hereafter, an appropriate statistical methodology has to be applied for the evaluation of scoring made by the competent experts, to reflect as accurately as possible the measured factors. Furthermore, statistical data related to the newly added factors have to be mapped and collected.

The next step to review the modified criteria system and its evaluation by the experts involved, than applicability of the finalized procedure will be tested by the assessment of existing farmers' markets. If critical points will be identified further optimization will be carried out until the goals are achieved.

It can be concluded that the underlying principles of a methodology suitable for supporting policy decision making were successfully determined, and it can definitely increase possibility of sustainable operation of farmers' markets. 


\section{REFERENCES}

Corum, V. (2009). Sylmar Farmers' Market Site Feasibility Report, Farmers' Markets America, November, 2009

Jolly, D. (2005). Starting a new farmers market, The Farmers Market Management Series Volume 1, 2005 UC Small Farm Center

Lohr, L., Diamond, A., Dicken, C., \& Marquardt, D. (2011). Mapping Competition Zones for Vendors and Customers in U.S. Farmers Markets, United States Department of Agriculture, Agricultural Marketing Service. September 2011

Northeast Organic Farming Association of Vermont (2009). Organizing \& Maintaining Your Farmers Market, support from Chittenden Bank, the Windham Foundation, the Vermont Agency of Agriculture, Food, and Markets, and the State of Vermont Farm To Family Program, 2nd Edition, 2009

Peters, M. J. (2008). Locating Farmers Markets: an evaluation methodology to inform site selection for farmers markets, Master of Urban Planning, University of Washington, Department of Urban Design and Planning, 2008

SFC2014 Short supply chain thematic sub-programme, DRAFT, 2014

Stephenson, G., Lev, L., \& Brewer, L. (2008). When Things Don't Work: Some Insight Why Famers' Markets Close, Special Report Number 1073, Oregon State University Extension Service, Corvallis, OR. 